\title{
Use of Slag Concrete in Construction of Underground Structures and Mines
}

\author{
Natalya Gilyazidinova ${ }^{1}$,Evgeniy Shabanov ${ }^{1, *}$, and Xuesheng Liu ${ }^{2}$ \\ ${ }^{1}$ T.F. Gorbachev Kuzbass State Technical University, 650000, Kemerovo, Russian Federation \\ ${ }^{2}$ Shandong University of Science and Technology, Qingdao 266590, Chin
}

\begin{abstract}
The paper considers the possibility of using slag concrete in underground construction. Technological parameters for production of slag concrete with the set properties are defined. The influence of the composition of slag concrete used in the conditions of mine construction on the change of physical and mechanical characteristics, durability and stability is determined. The limits of technological parameters of slag concrete preparation are established. The possibilities of combined use of blast-furnace slags and clinkers for concrete in mine construction are substantiated. The chemical composition of blast furnace slag and the possibility of its application in the composition of concrete is described, the interaction of an aggregate - Portland cement with blast furnace slag is studied. The technique for conducting experiments to determine the rate of strength gain of different types of concrete is described. The rate of strength gains of heavy concrete and the rate of strength gain of slag concrete with additives and without additives have been compared. The possibility of application of this slag concrete in the process of concreting with the use of sliding formwork has been studied.
\end{abstract}

\section{Introduction}

Underground construction, owing to a number of its specific features, is obviously predisposed to use high-strength concrete. In underground construction strength of concrete is a very important, but not the only defining factor. Water tightness and durability are very important too. Durability and water tightness are composed of resistance to sulphatic aggression, resistance to leaching and a number of less significant factors. In the construction of underground structures and mines they mainly use heavy concrete with fine and coarse aggregates [1-3].

Crushed stone in Kuzbass becomes scarce, that's why the tendency of regular rise in prices is observed (about 30\% in a year). At the same time, there is a large stock of waste of metallurgical and fuel enterprises in the region's dumps, i.e. ash and slag [4]. The chair of construction production and real estate has studied a possibility to use crushed stone consisting of blast-furnace slag and mixtures of ash and slag from thermal power plants for preparation of heavy concrete, which is proposed to be used for the manufacture of precast and monolithic structures in underground construction [5].

\footnotetext{
* Corresponding author: shabanovea@kuzstu.ru
} 
The analysis of physical and chemical properties of slag predetermined the creation of high-quality ash slag concrete. A number of the indicators characterizing the possibility of using blast furnace slag as aggregates of concrete and allowing to judge their hydraulic activity is established.

\section{Method of research}

In accordance with the Construction Norms and Regulations SNiP 2.03.01* -84 "Concrete and reinforced concrete structures", it is recommended to use only acidic slags in the concrete whose basicity is less than one. Kuznetsky slags contain in their composition 37 to $39 \%$ of $\mathrm{CaO}$, their basicity factor is 0.89 , that's why they belong to acid compositions and can be used as aggregates for concrete with their module of hydraulic activity varying from 0.34 to 0.4. By their quality indicator (the ability when finely crushed to interact with water like cement), blast-furnace slags belong to semi-active ones. Their curing is ensured only in the presence of cement clinker.

By their chemical composition, blast-furnace slags are closer to Portland cement, at the same time, they contain an increased amount of silicon dioxide and alumina, and a decreased amount of calcium oxide [6-7]. Slag aggregates aren't inert, in a contact zone they react with related cements, this leads to growth in uniformity and to improvement of concrete structure [8].

The most part of the monolithic concrete used in construction of underground structures and mines, is placed in underground structures and hardens at low temperatures. The normal conditions of concrete curing are temperature of +15 to $+20{ }^{\circ} \mathrm{C}$ and relative humidity of 90 $100 \%$. With decrease in concrete curing temperature, the concrete strength increases more slowly than as established by numerous studies [9-10]. It is interesting to study the comparative change in strength of concrete based on crushed slag stone at various temperature of storage, in particular at $+5{ }^{\circ} \mathrm{C}$ which is characteristic to underground mine construction.

\section{Results and Discussion}

For further analysis, experiments were conducted in which a part of sample cubes made of slug concrete with a different composition with additives of technical modified lignosulfonates (LSTM) and $\mathrm{LSTM}+\mathrm{CaCl}_{2}$, and control samples of normal heavy concrete were placed in a cooling chamber and kept at a temperature of $5 \pm 2{ }^{\circ} \mathrm{C}$, and another part was stored in normal conditions [11].

The strength of twin samples was determined after their visual examination at the age of 3,5 and 7 days at curing temperatures $+5{ }^{\circ} \mathrm{C}$ (Table 1) and $+15^{\circ} \mathrm{C}$ (Table 2).

Table 1. Results of testing concrete of various compositions at curing temperature of $+5{ }^{\circ} \mathrm{C}$.

\begin{tabular}{|c|c|c|c|}
\hline $\begin{array}{c}\text { Age of concrete } \\
\text { samples, day }\end{array}$ & $\begin{array}{c}\text { Strength of slag } \\
\text { concrete samples } \\
\text { with the addition of } \\
\text { LSTM at a water- } \\
\text { cement ratio of } \mathbf{0 . 5} \\
\text { MPa }\end{array}$ & $\begin{array}{c}\text { Slag concrete } \\
\text { without additives at } \\
\text { water-cement ratio } \\
\text { of } \mathbf{0 . 5} \mathbf{M P a}\end{array}$ & $\begin{array}{c}\text { Heavy concrete with } \\
\text { the addition of } \\
\text { LSTM at a water- } \\
\text { cement ratio of } 0.5 \\
\text { MPa }\end{array}$ \\
\hline 3 & 9.6 & 6.2 & 6.9 \\
\hline 5 & 13.2 & 14.4 & 10.2 \\
\hline 7 & 15.4 & 16.2 & 12.5 \\
\hline
\end{tabular}


Table 2. Results of testing concrete of various compositions at curing temperature of $+15{ }^{\circ} \mathrm{C}$.

\begin{tabular}{|c|c|c|c|}
\hline $\begin{array}{c}\text { Age of concrete } \\
\text { samples, day }\end{array}$ & $\begin{array}{c}\text { Strength of slag } \\
\text { concrete samples } \\
\text { with the addition of } \\
\text { LSTM at a water- } \\
\text { cement ratio of } \mathbf{0 . 5} \\
\mathbf{M P a}\end{array}$ & $\begin{array}{c}\text { Slag concrete with- } \\
\text { out additives at } \\
\text { water-cement ratio } \\
\text { of } \mathbf{0 . 5} \mathbf{M P a}\end{array}$ & $\begin{array}{c}\text { Heavy concrete with } \\
\text { the addition of } \\
\text { LSTM at a water- } \\
\text { cement ratio of } \mathbf{0 . 5} \\
\mathbf{M P a}\end{array}$ \\
\hline 3 & 12.1 & 10.6 & 9.4 \\
\hline 5 & 14.6 & 13.9 & 12.4 \\
\hline 7 & 17.8 & 18.6 & 15.5 \\
\hline
\end{tabular}

Comparison of test results of types of concrete with various compositions and standard characteristics of relative strength of concrete based on natural aggregates, hardening at the same temperature according to the data of normative literature (Figs. 1 and 2).

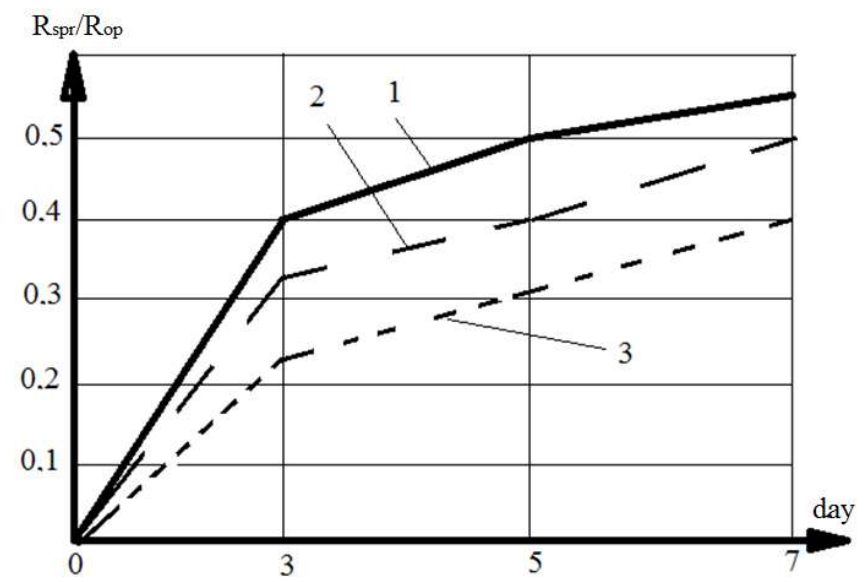

Fig. 1. Test results at curing temperature of $+5{ }^{\circ} \mathrm{C}: 1-$ heavy concrete with the addition of LSTM at a water-cement ratio of $0.5 ; 2$ - slag concrete without additives at a water-cement ratio of $0.5 ; 3$ - strength of slag concrete samples with the addition of LSTM at a water-cement ratio of 0.5 .

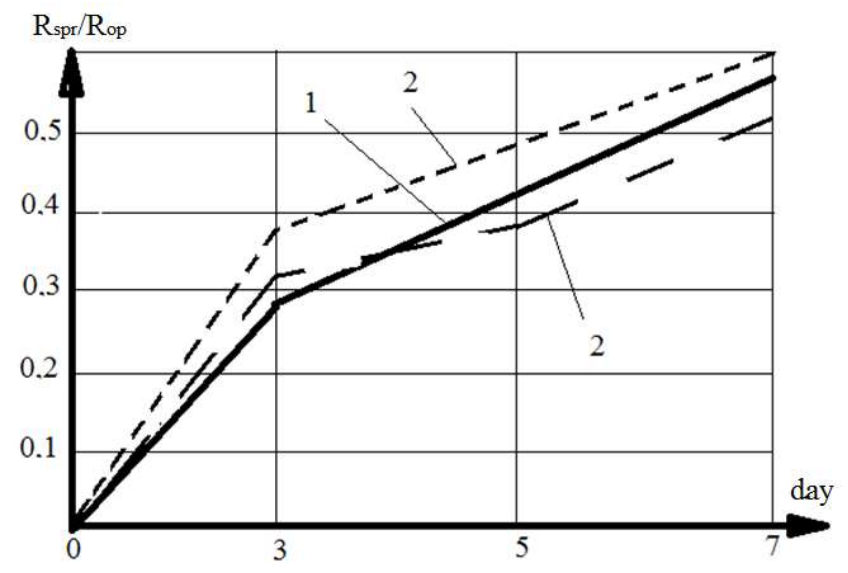

Fig.2. Test results at curing temperature of $+15{ }^{0} \mathrm{C}: 1$ - heavy concrete (average normative characteristics); 2 - heavy concrete with the addition of LSTM at a water-cement ratio of $0.5 ; 3$ strength of samples of slag concrete with the addition of LSTM at a water-cement ratio of 0.5.

As can be seen from the graphs, the strength characteristics of slag concrete not only exceed the normative characteristics of heavy concrete, but also have higher absolute values 
than the same indicators of concrete based on natural aggregate.

Introduction of $2 \%$ of $\mathrm{CaCl}_{2}$ in the composition of concrete according to normative literature ensures an increase in concrete strength at low temperatures to $75 \%$ versus the design strength of the concrete hardening in normal conditions. According to experimental data, the actual increase in strength was $75-87 \%$ for heavy concrete, and $92-133 \%$ for constructive concrete using slag crushed stone. The above shows that slag concrete is more effective to be used at low temperatures than common types of concrete using natural materials.

Of particular interest is the question of reasonability of using slag concrete in sliding formwork. According to data of technical and normative literature, concrete applied in a sliding formwork must meet the requirements, including: mobility of concrete mixture 5 to 9 $\mathrm{cm}$, slump of a standard cone, strength that allows us to release concrete from the formwork - 0.15-0.3 MPa; time during which concrete achieves demolding strength 4-12 h, the corresponding speed of formwork advancing $2-8 \mathrm{~cm} / \mathrm{h}(50-200 \mathrm{~cm} /$ day $)$.

To determine the reasonability of using slag concrete for the indicated purposes, the concrete mixture with mobility of about $8-9 \mathrm{~cm}$ was placed in removable metal formwork and it was compacted by a ramming method. For the purpose of improving the rheological characteristics of the concrete mixture, LSTM was entered into its composition in the ratio of $0.15 \%$ of the cement mass in terms of dry matter. Concrete was cured in the cold chamber at a temperature about +5 to $+7{ }^{\circ} \mathrm{C}$. That simulated the conditions of underground mine construction. In 3.5 hours, it was released from the removable formwork. That corresponded to the speed of formwork advancing at about $200 \mathrm{~cm}$ per day. Visual inspection of the sample showed that on its surface there were no shrinking cracks, spall and other defects.

There was no instrumental technique to determine the concrete strength at early age, that's why its suitability for application in a sliding formwork was determined by palpating and by local compression test (bearing test).

It is accepted that the speed of sliding formwork movement is properly assigned if palpating doesn't leave a deep dent. The experiments confirmed compliance of the studied composition of concrete with the specified requirement. The cubical and prismatic concrete strength was defined by concrete bearing test.

It is known that the temporary bearing resistance of concrete is determined by the following formula (1)

$$
\sigma_{\mathrm{S} . \mathrm{sok}}=1,5 \sigma_{\text {B.U. }}=1,5 \cdot 0,8 \sigma_{\mathrm{U}}=1,2 \sigma_{\mathrm{U}} \sigma_{\mathrm{S}}
$$

where

$\sigma_{B, U}$ - prismatic concrete strength

бu - cubical concrete strength,

and from which follows the cubical concrete strength (2)

$$
\sigma_{\mathrm{U}}=\sigma_{\mathrm{S} . \mathrm{sok}} / 1,2
$$

To determine $\sigma_{\text {S.sok }}$, two stamps are put on the top open surface of a sample, in its center, - one with the bearing area of $1.01 \mathrm{~cm}^{2}$, the other $-0.39 \mathrm{~cm}^{2}$. Loading was transmitted through them on concrete in steps.

\section{Conclusion}

During the tests, it was established that at local loading of $5.94 \mathrm{~kg} / \mathrm{cm}$ in concrete under the stamp and on its border there were no plastic deformations formed; with the load increasing to $7.92 \mathrm{~kg} / \mathrm{cm} 2$, the stamp depth in concrete was $0.5 \mathrm{~mm}$; at loading of $10.25 \mathrm{~kg} / \mathrm{cm}^{2}$, it was 
$2.8 \mathrm{~mm}$. Thus, the loading equal to $6 \mathrm{~kg} / \mathrm{cm}^{2}$ with some safety margin can be considered critical, responding to temporary bearing resistance. It means that the cubical concrete strength in 3 to $4 \mathrm{~h}$ after it is placed in the formwork will be $\sigma_{U}=6: 1.2=5 \mathrm{~kg} / \mathrm{cm}$, and that the received value exceeds the value of the maximal required demolding strength of concrete in sliding formwork by more than 1.6 times.

Therefore, the use of constructive concrete with aggregates from a mixture of blastfurnace slags and clinkers in the sliding formwork is expedient and sufficiently effective.

\section{References}

1. K. Kovler, Vestnik of Tomsk State University of Architecture and Building, 1, 71 (2015)

2. A.S. Zhiv, B.R. Isakulov, Construction and Architecture, 3:23, 61 (2014)

3. G. Komitov, V. Rasheva, I. Binev, I. Kiryakov, European Journal of Technical and Natural Sciences, 4, 20 (2016)

4. M. Ivanou, V.M. Chertkov, Materials of VI junior researchers' conference: In 3 Parts. Ministry of education of Belarus, 134, 77 (2014)

5. Zh.K. Bakhov, O.G. Vorobyov, Optimization methodology and management of environmental safety of geotechnical systems (on the example of chemical enterprises) (TTGD, Tambov, 2018)

6. E.S. Makhotkina, O.S. Ponomareva, L.G. Kolyada, Solid State Phenomena, 265, 1081 (2017)

7. D.N. Togobitskaya, N.M. Mozharenko, A.I. Bel'kova, D.A. Stepanenko, Metallurgical and Mining Industry, 2:4, 249 (2010)

8. K.V. Schuldyakov, L.Y. Kramar, B.Y. Trofimov, Procedia Engineering, 1433, 88 (2016)

9. D.K. Panesar, G.H.Y. C International Journal of Mechanical Sciences, 144, 865 (2018)

10. D.P. Bentz, P.E. Stutzman, F. Zunino, Materials and Structures, 50:3, 173 (2017)

11. N.V. Gilyazidinova, N.Yu. Rudkovskaya, T.N. Santalova, The 8th Russian-Chinese Symposium Coal In The 21st Century: Mining, Processing And Safety, 62 (2016) 